University of Michigan Law School

University of Michigan Law School Scholarship Repository

Articles

Faculty Scholarship

1917

\title{
Safeguarding the Criminal Defendant
}

Edson R. Sunderland

University of Michigan Law School

Available at: https://repository.law.umich.edu/articles/1362

Follow this and additional works at: https://repository.law.umich.edu/articles

Part of the Constitutional Law Commons, and the State and Local Government Law Commons

\section{Recommended Citation}

Sunderland, Edson R. "Safeguarding the Criminal Defendant." Mich. L. Rev. 15 (1917): 423-5.

This Response or Comment is brought to you for free and open access by the Faculty Scholarship at University of Michigan Law School Scholarship Repository. It has been accepted for inclusion in Articles by an authorized administrator of University of Michigan Law School Scholarship Repository. For more information, please contact mlaw.repository@umich.edu. 


\section{Michigan LAW RevieW}

PUBLISHED YONTHLY DURING THE ACADEMIC YEAP, EXCLUSTVE OF OCTOBER, DY THE

LAW FACULTY OF THE URIVERSTY OF MICHICAN

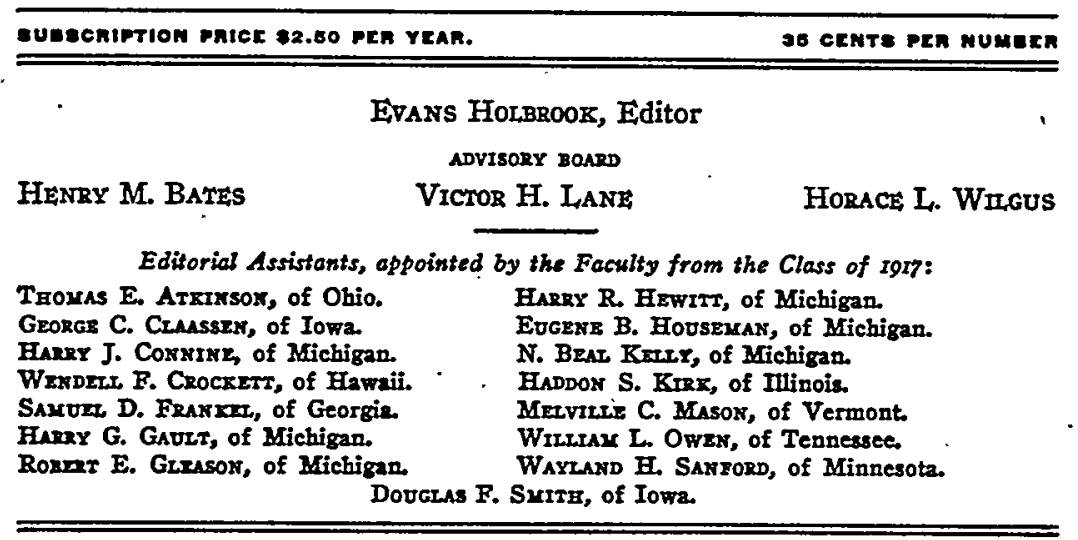

\section{NOTE AND COMMENT}

Safeguarding the Criminar, Defendant.-Every now and then a new attack is made somewhere in the United States upon the rule prohibiting comment before the jury upon the fact that the defendant in a criminal case has not testified as a witness in his own behalf. At the present time an effort of this kind is being made in the Michigan legislature, and the introduction of the bill drew quite a little storm of protest from the State press as a dangerous inroad upon our ancient guarantees of personal liberty and security. In fact, however, it directly touches nothing more ancient than a statutory privilege which dates from the year I86r. By the Public Acts of that year the disability of parties to actions to testify as witnesses in this State was removed, but it was expressly provided that defendants in criminal cases could not be compelled to testify, but might do so or not at their own pleasure. (Act No. I25, \$2). In I88I an amendment to this statute was passed providing, as to the defendant in a criminal case, that "his neglect to testify shall not create any presumption against him, nor shall the court permit any reference or comment to be made to or upon such neglect." (Pub. Acts, 188I, No. 245). And this is the form it retains in the Judicature Act. (Ch. 17, \$64).

Conceiving this statute to be merely a legislative interpretation of the constitutional provision that "No person shall be compelled in any criminal case to be a witness against himself" (Const. 1850, Art. VI, \$32; Const. 
I909, Art. II, §I6), the legislature is considering the proposal of a constitutional amendment to permit such comment. And this is probably necessary, for judicial opinion seems to incline toward the view that comment upon a failure to testify is a violation of this provision against compulsory selfincrimination. CooLey, Const. LIM. (7th Ed.) 447; People v. Tyler, $36 \mathrm{Cal}$. 522 ; State v. Cameron, 40 Vt. 555; Commonwealth v. Harlow, IIo Mass. $41 \mathrm{II}$; Commonwealth v. Scott, 123 Mass. 239. Only in Maine, it appears, has such comment been expressly held to be compatible with this constitutional privilege. State v. Bartlett, $55 \mathrm{Me}$. 200, 217; State v. Banks, $78 \mathrm{Me}$. 490. The New Jersey cases are not germane because in that State the constitution does not have a similar provision. Parker v. State, 6r N. J. L. 308.

The wisdom of the rule prohibiting comment upon a defendant's failure to testify is a matter which may well be questioned. In the first place, there is an artificiality and lack of candor in the ostrich-like refusal to admit the existence of a perfectly obvious fact. As the Supreme Court of New Jersey says, the inference which follows from a failure to testify "is natural and irresistible. It will be drawn by honest jurymen, and no instructions will prevent it. Must a court refrain from noticing that which is so plain and forcible an indication of guilt?" Parker $\nabla$. State, supra.

But a more serious objection is that the rule destroys a perfectly reliable and legitimate means for aiding the jury to reach a just verdict. Fleeing from arrest, giving contradictory or improbable accounts of the matters in issue, refusing to account for the possession of stolen property,-aill these are acts which suggest inferences as to guilt which are conceded to be proper for the jury to consider. Conduct at the trial in refusing to give testimony which could ordinarily be damaging only if the defendant were guilty, is an act equally suggestive of inference. If the conduct of the defendant before the trial is available, why should his conduct at the trial be deemed too dangerous and unjustly prejudicial for the jury to consider? The rule evinces an astounding lack of confidence in the jury.

This much is clear, that the rule here considered has nothing to do with due process of law, and is not guaranteed to the citizens of the several States by the. United States Constitution. It is at most a mere special application of a more general rule, namely, against self-incrimination, and even this latter rule is merely one of expediency and "has no place in the jurisprudence of civilized and free countries outside the domain of the common law, and it is nowhere observed among our own people in the search for truth outside the administration of the law." Twining v. New Jersey, 2II U. S. 78, II3. And it is also clear that in England and her colonies, where the guarantees of the common law are held in as high regard as with us, no such rule as that prohibiting comment on failure to testify is recognized. Regina v. Rhodes [1899] I Q. B. 77; Kops v. Regina [1894] App. Cas. New South Wales, 650, affirming Id., I4 N. S. Wales L. Rep. I50.

It is also interesting to note that the large and influential Law Reform Committee of the New York Bar Association, in a report made in December, I9I4, unanimously recommended the enactment of legislation similar to that now proposed in the Michigan legislature. 
A corollary to the rule against comment is involved in the recent and much discussed case of Caminetti, et al. v. United States, 37 Sup. Ct. 192, decided Jan. 15, 1917. In that case the defendant took the stand and testified as to events up to a certain point, but he stopped short there and refused to testify further. This failure to testify to subsequent events was put before the jury by an instruction from the court as evidence for their consideration. It was contended on behalf of the defendant that this was error, under the federal statute (Act of March 16, 1878, 20 Stat. 30, c. 37). which had been held to prohibit comment on a failure to testify. Wilson $\nabla$. United States, I49 U. S. 60. The Supreme Court of the United States held, affirming the Circuit Court of Appeals below, that when the defendant took the stand he voluntarily relinquished his privilege of silence together with the immunity from comment thereon, and could not stop his testimony at any point he saw fit "without subjecting his silence to the inferences to be naturally drawn from it." The same point had previously been decided the other way by two United States Circuit Courts of Appeals. Balliet $\nabla$. United States, I29 Fed. 689,64 C. C. A. 20I; Myrick v. United States, 219 Fed. I, I34 C. C. A. 6rg. The decision in the Diggs case is in harmony with the generally accepted view. WrGMORE, EvID., \$2273(4), and note. E. R. S. 